\title{
Assessment of Levels and Safe Factor Index of Heavy Metals in Soils Around Diobu, Port Harcourt, Nigeria
}

\author{
Iyama, W. A. ${ }^{1}$, Edori, O. $\mathrm{S}^{2 *}$ \\ ${ }^{1}$ School of General Studies, Rivers State College of Health Science and Management Technology, Rumueme, \\ Port Harcourt, Rivers State, Nigeria. \\ ${ }^{2}$ Department of Chemistry, Ignatius Ajuru University of Education, Rumuolumeni, Port Harcourt, Rivers State \\ *Corresponding Author: Edori Enize Simeon, Department of Chemistry, Ignatius Ajuru University of \\ Education, Rumuolumeni, Port Harcourt, Rivers State, Nigeria
}

\begin{abstract}
This study was aimed at determining the variations of some heavy metals in soil sample between Mile $3\left(M_{3}\right)$ and Mile $4\left(M_{4}\right)$, all in Diobu, which are both primarily business and residential areas when compared to the control represented by the Rivers State University (RSU), Port Harcourt. The Azuka Index $\left(A_{i}\right)$ was used to determine the Safety Factor Index. The levels and distribution of seven heavy metals ( Fe, $\mathrm{Pb}, \mathrm{Cu}$, $\mathrm{Cd}, \mathrm{Cr}, \mathrm{Ni}, \mathrm{As})$ in soil (0-25 cm depth) from the area using Atomic Absorption Spectrometer (AAS, Perkin Elmer 2380) were assessed. The results showed that in $M_{3}, \mathrm{Fe}$ (1418.303), Cd (2.692), Pb (7.646), Ni (7.412) and $\mathrm{M}_{4}, \mathrm{Fe}$ (1162.011), $\mathrm{Cd}$ (1.436), $\mathrm{Pb}$ (7.372), $\mathrm{Ni}$ (5.384) were above WHO/FAO/FEPA recommended permissible limits for soils. High percentage variations occurred between the study stations and the controls, $\mathrm{M}_{3} / \mathrm{RSU}$ for $\mathrm{Fe}, \mathrm{Cd}, \mathrm{Cr}, \mathrm{Ni}, \mathrm{As}$ and $\mathrm{M}_{4} / \mathrm{RSU}$ for $\mathrm{Cd}, \mathrm{Cr}, \mathrm{Ni}$, As respectively. Though, the result of the ANOVA showed p-value of $0.2845(\alpha=0.05)$ meaning no significant difference within the $M_{3}, M_{4}$ and RSU stations was also corroborated by the t-test result for $M_{3} / R S U$ control and $M_{4} / R S U$ control which were 1.013 and 1.037 respectively at 0.05 significant levels. The mile 3 study station was observed to have more anthropic inputs which also showed in the variations from the Mile 4 results. The above results showed that only Cu in the Mile 4 study station certified a safe range while all the heavy metals exceeded safe limits especially $C d$, As and $N i$. The concentration distribution trend for the heavy metals studied were; $\mathrm{M}_{3}(\mathrm{Fe}>\mathrm{Cr}>\mathrm{Cu}>\mathrm{Pb}>\mathrm{Ni}>\mathrm{As}>\mathrm{Cd}) ; \mathrm{M}_{4}$ $(\mathrm{Fe}>\mathrm{Pb}>\mathrm{Cr}>\mathrm{Cu}>\mathrm{Ni}>\mathrm{As}>\mathrm{Cd}) ; \mathrm{RSU}(\mathrm{Fe}>\mathrm{Cu}>\mathrm{Pb}>\mathrm{Cr}>\mathrm{Ni}>\mathrm{As}>\mathrm{Cd})$. The increasing concentrationss of these heavy metals in the soils of these areas stands a threat to health of the inhabitants; hence must be monitored and adequate measures taken by appropriate authorities of government
\end{abstract}

Keywords: Heavy metals, Azuka safe index, Mile3, Mile 4, Anthnropic, sample variation

\section{INTRODUCTION}

According to Fergusson (1990), inorganic elements which are five times the specific gravity of water are considered as heavy metals. Heavy metals occur naturally in the ecosystem, most of them in trace quantities (Adamo et al., 2002). Any metal considered toxic may be called heavy metal not minding the weight, atomic mass or density (Singh, 2007). Heavy metals are a member of an ill-defined subset of elements that exhibit metallic properties. These include the transition metals, some metalloids, lanthanides, and actinides. One source defines heavy metal as one of the common transition metals, such as copper, lead, and zinc. These metals are a cause of environmental pollution from sources such as leaded petrol, industrial effluents, and leaching of metal ions from the soil into lakes and rivers by acid rain (Dictionary of Chemistry, 2000). Heavy metals are generally referred to as those metals which possess a specific density of more than $5 \mathrm{~g} / \mathrm{cm}^{3}$ and adversely affect the environment and living organisms (Järup, 2003). Heavy metals pollution of the soil is caused by various metals especially $\mathrm{Cu}, \mathrm{Ni}, \mathrm{Cd}, \mathrm{Zn}, \mathrm{Cr}$, and $\mathrm{Pb}$ (Hinojosa et al., 2004). Similarly, heavy metals are characterized by relatively high density and high relative atomic weight with an atomic number greater than 20 .

Heavy metals occur naturally in the soil environment from the pedogenetic processes of weathering of parent materials at levels regarded as trace $\left(<1000 \mathrm{mgkg}^{-1}\right)$ and seldom toxic (Kabata-Pendias \& Pendias, 2001; Pierzynski et al., 2000). Due to the disturbance and acceleration of nature's slowly occurring geochemical cycle of metals by man, most soils of rural and urban environments may accumulate one or more of the heavy metals above defined background values high enough to cause risks to human health, plants, animals, ecosystems, or other media (D'Amore et al., 2005). 
Similarly, Arsenic, lead, cadmium (Cd), and mercury have serious health implications within the heavy metals (Agency for Toxic Substances and Disease Registry, ATSDR, 2007; Csavina et al., 2012; Sharma et al., 2014; Gupta et al., 2015a). Arsenic, Cd, mercury, and lead have patho-physiological significance as their bioaccumulation in living systems may cause severe damage to vital organs (Sharma et al., 2014; Gupta et al., 2015b Heavy metals can damage and alter the functioning of organs such as the brain, kidney, lungs, liver, and blood. Heavy metal toxicity can either be acute or chronic effects.

Although plants require certain heavy metals for their growth and upkeep in the soil, excessive amounts of these metals can become toxic to plants. Some of the direct toxic effects caused by high metal concentration include inhibition of cytoplasmic enzymes and damage to cell structures due to oxidative stress (Duruibe et al., 2007; Young, 2005). Similarly, acid leaching and electrokinetics extract metals from soil. Heavy metals pollution is a menace to our environment as they are foremost contaminating agents of our food supply (Chauhan \& Chauhan, 2014). Vegetables get contaminated by absorbing heavy metals from polluted air, soil, and water (Sharma et al., 2008; Singh et al., 2010). Heavy metals pollution in soil and water has a lot of adverse effects and thus is of great concern to public health, agricultural production, and environmental health (Goyer, 1997; Fergusson, 1990; Msaky \& Calvet, 1990; Ma et al., 1994). Soil pollution results mainly from disposal of industrial and urban wastes as well as usage of agrochemicals (Buchauer, 1973; McBride, 2003; Demirezen \& Aksoy, 2006). Many growing areas in the developing countries are vulnerable to air pollution due to the fact that heavy metals containing aerosols are normally deposited on soil surface and get absorbed by vegetables or sometimes get deposited on plant leaves (Duruibe et al., 2007). The absorption of heavy metals by the plants from the soil depends on different factors, including application of agrochemicals, solubility of heavy metals, soil $\mathrm{pH}$, soil type, and plant species (Young, 2005; Gupta et al., 2013).

Heavy metals are one of the most widespread contaminants in the environment. They cause environmental pollution from sources such as industrial effluents, mine tailings, land application of fertilizers, atmospheric deposition and leaching of metal ions from the soil into lakes and rivers by acid rain (Chauhan \& Chauhan, 2014; Sharma et al., 2008; Singh et al., 2010).

Research has shown that the main sources of heavy metals in the environment include geogenic, industrial, agricultural, pharmaceutical, domestic effluents, and atmospheric (Goyer, 1997). Environmental pollution is very prominent in point source areas of soil like mining, foundries and smelters, and other metal-based industrial operations (Goyer, 1997; Singh et al., 2010; Chauhan \& Chauhan, 2014). The most common heavy metals found at contaminated sites, in order of abundance are $\mathrm{Pb}, \mathrm{Cr}, \mathrm{As}, \mathrm{Zn}, \mathrm{Cd}, \mathrm{Cu}$, and $\mathrm{Hg}$ (Gupta et al., 2013).

The advancing demand for information technology has resulted in large volumes of e-waste globally (Wagner, 2009). Accordingly, e-waste contains many different hazardous materials such as $\mathrm{Cd}, \mathrm{Pb}, \mathrm{As}$, $\mathrm{Be}, \mathrm{Cr}, \mathrm{Hg}$, polycyclic aromatic hydrocarbons (PAHs), chlorofluorocarbons, polybrominated diphenyl ethers and dioxin-like compounds and non-hazardous metals like $\mathrm{Zn}, \mathrm{Cu}, \mathrm{Se}$, precious metals $\mathrm{Ag}, \mathrm{Au}$, $\mathrm{Pt}$, among others. These significant harmful environmental impacts when not properly disposed-off especially to the soil (Lim, 2010; Tsydenova \& Bengtsson, 2011). However, the dose, concentration and receptor organ can convert non-hazardous chemicals such as $\mathrm{Zn}, \mathrm{Cu}$ and $\mathrm{Se}$ to hazardous ones in humans and ecosystems (Musee, 2011; Tchounwou et al., 2012; Itai et al., 2014).

Heavy metals are natural constituents of the earth's crust and soils, but indiscriminate anthropogenic inputs activities have altered their geochemical cycles and biochemical balance. This results in accumulation of metals in plant parts having secondary metabolites, which is responsible for a particular pharmacological activity. Research has also shown that prolonged exposure to heavy metals such as cadmium, copper, lead, nickel, and zinc can cause deleterious health effects in humans. All metals are toxic at higher concentrations (Chronopoulos et al., 1997). Excessive levels can be damaging to the organism. Any metal (or metalloid) species may be considered a "contaminant" if it occurs where it is unwanted, or in a form or concentration that causes a detrimental human or environmental effect. Heavy metals include lead $(\mathrm{Pb})$, cadmium $(\mathrm{Cd})$, mercury $(\mathrm{Hg})$, arsenic $(\mathrm{As})$, chromium $(\mathrm{Cr})$, copper $(\mathrm{Cu})$, selenium (Se), nickel (Ni), silver $(\mathrm{Ag})$, and zinc $(\mathrm{Zn})$. Other less common metallic contaminants include aluminium ( $\mathrm{Al})$, cesium $(\mathrm{Cs})$, cobalt $(\mathrm{Co})$, manganese $(\mathrm{Mn})$, molybdenum $(\mathrm{Mo})$, strontium $(\mathrm{Sr})$, and uranium (U) (Mcintyre, 2003). Living organisms require varying amounts of heavy metals. Iron, cobalt, 
copper, manganese, molybdenum and zinc are required by humans (Lane \& Morel, 2009). Heavy metals such as mercury, plutonium, and lead are toxic metals that have no known significant effect on organisms, and their accumulation over time in the bodies of animals can cause serious illness. Certain elements that are normally toxic are for certain organisms or under certain conditions, beneficial. Examples include vanadium, tungsten, and even cadmium (Ernst, 2002; Lane et al., 2005; Singh et al, 2010).

Metals concentration in soil can extend to as high as $100,000 \mathrm{mg} / \mathrm{kg}$ (Long et al., 2002). Heavy metals are the major inorganic contaminants and relatively large area of land can be contaminated (Halim et al., 2002). Notwithstanding the origin of the metals in the soil, excessive concentrations of many metals can lead to soil quality degradation, crop yield reduction, and poor quality of agricultural products, which poses significant hazards to human, animal, and ecosystem health (Long et al., 2002). The knowledge of the present heavy metal concentration in the soil around this busy environment will guide the academic and government sectors to make rightful decisions and proffer adequate mitigating measures to protect the ecosystem and man. There is therefore the ardent need to assess the variations in soil heavy metal content so as to monitor its impact on the soil, plant and human health risk implications.

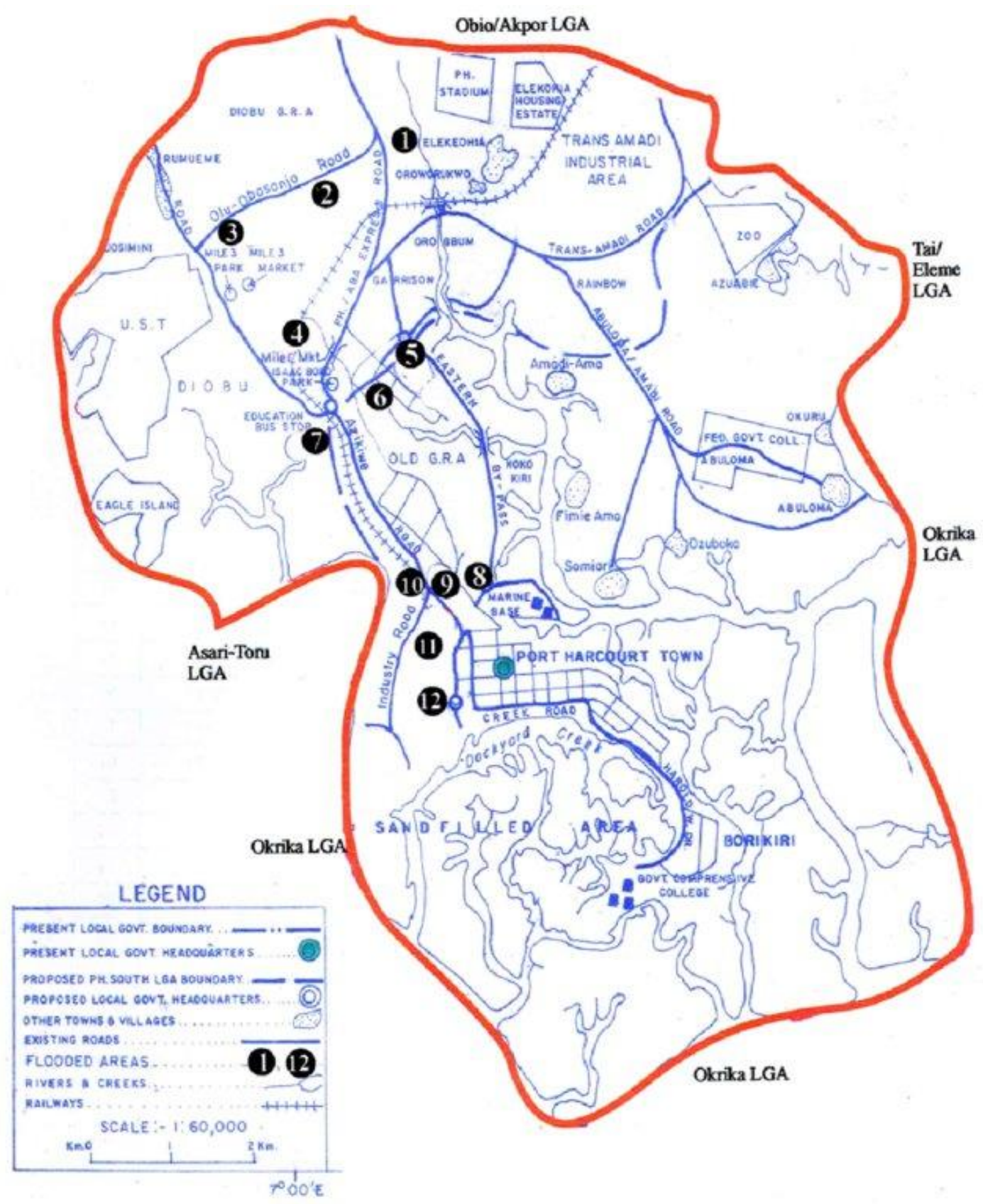

Figure1. Map of Port Harcourt (Nwankwoala \& Warmate, 2014) 


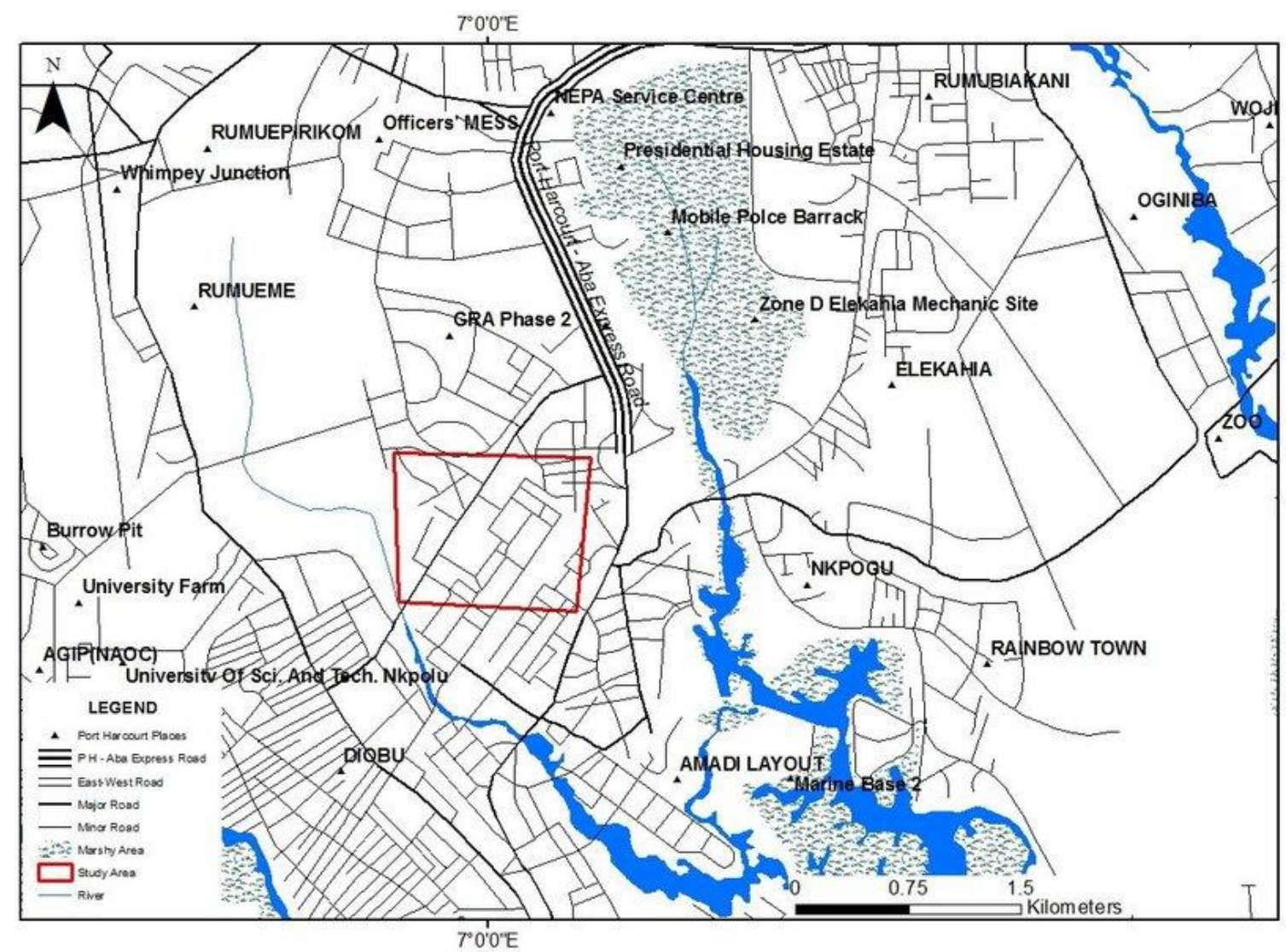

Figure2. Image Uploaded by Nwankwoala and Warmate (2014)

\section{Materials AND Methods}

\subsection{Study Area}

This study was conducted in Port Harcourt and Obio-Akpor local government areas of Rivers State, Nigeria. Port Harcourt is known as port town and capital of Rivers State, Niger Delta, Southern Nigeria. It lies along the Bonny River (eastern tributary of the Niger River) 41 miles $(66 \mathrm{~km})$ upstream from the Gulf of Guinea. Port Harcourt was founded in 1912 in an area traditionally occupied by the Ijo (Ijaw), Okrikans, and Ikwere people. It began to serve as a port (named for Lewis Harcourt, then colonial secretary) after the opening of the rail link to the Enugu coalfields in 1916. Now one of the nation's largest ports, its deepwater (23 feet, about 7 metres) facilities handle the export of palm oil, palm kernels, and timber from the surrounding area, coal from Anambra state, tin and columbite from the Jos Plateau, and, since 1958, petrole um from fields in the eastern Niger River delta. Port Harcourt has bulk storage facilities for both palm oil and petroleum. In the 1970s the port was enlarged with new facilities at nearby Onne. Today, Port Harcourt is made up of two large local governments of Port Harcourt City and Obio-Akpor to which the two study locations are sited (Mile 3 and Mile 4 respectively).

The sample stations are basically areas designated as residential but due to increased population has become centre of business activities though no major industries are located. These areas are made up of Institutions such as the Rivers State University, the former School of Nursing and the Rivers State College of Health Science and Management Technology, Port Harcourt. The only major company of interest is the Nigerian Agip Oil Company (NAOC) whose office is located within the study stations. The map of Port Harcourt showing the areas of study are in Figures 1 and 2. The coordinates of the study stations were as follows; Control station of RSU for Ta, Tb, Tc (

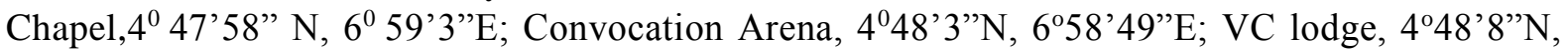
6 58'37" respectively); Mile 3 for Ta, Tb and Tc (RSU Round About, 4 48'19” N, 6059'16”'E; Mile

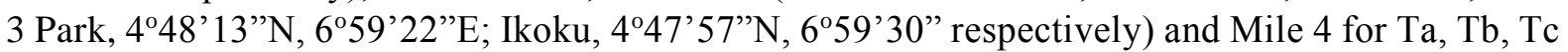
(Agip Flyover, 448'51" N, 659'2”'E; OCC Town Hall, 449'10”N, 658'56"E; Whimpey Junction, $4^{\circ} 49^{\prime} 50^{\prime \prime} \mathrm{N}, 6^{\circ} 58^{\prime} 53^{\prime \prime}$ respectively). 


\subsection{Description of the Sampling Sites}

The sampling sites were the Mile $3\left(\mathrm{M}_{3}\right)$ and Mile $4\left(\mathrm{M}_{4}\right)$ study Stations while the Rivers State University served as the Control station. The study area was divided into three (3) sites depending on the prevalent activity around the area. These areas are purely residential and business districts but the Rivers State University Site (control) was mainly areas where student population density was higher. Each sampling site was $350 \mathrm{~m}$ apart from the designated study station. The control station which was the University was $1.5 \mathrm{~km}$ away from the Mile $3\left(\mathrm{M}_{3}\right)$ station and $3 \mathrm{~km}$ away from the Mile $4\left(\mathrm{M}_{4}\right)$ sampling site respectively.

\subsection{Sample Collection}

In each of the selected sites, three quadrats were marked. In each quadrat, three core soil samples were collected randomly at depth $0-25 \mathrm{~cm}$ using a soil auger and put together to form a composite sample. The composite samples were well-mixed and sub-samples taken (Qin et al., 2014). Three soil replicates were collected from each site, making a total of nine (9) soil samples from the study area. The soil samples were kept in zip-locked plastic bags, labelled and transported to the laboratory for further treatment and analysis. The soil samples were air-dried at room temperature for 4 days, and ground to fine powder. They were then sieved with a $2 \mathrm{~mm}$ sieve to remove the coarse soil components. Sub-samples of the sieved soils were then taken for soil heavy metals analysis.

\subsection{Soil Sample Preparation and Analysis}

The soil samples collected from the sub-stations were thoroughly mixed to form a composite sample; then, the samples were oven-dried at $105^{\circ} \mathrm{C}$ for six hours until constant weight was attained. The ovendried samples were then crushed and sieved through $2.0 \mathrm{~mm}$ wire mesh. Afterwards, thorough digestion of the representative samples were done. For each sample, $1 \mathrm{~g}$ was digested in $10 \mathrm{~mL}$ of $1: 1 \mathrm{HNO}_{3}$ and heated to $95^{\circ} \mathrm{C}$ to dry and thereafter refluxed for 10 minutes without boiling. After cooling, $5 \mathrm{~mL}$ of concentrated $\mathrm{HNO}_{3}$ was once again added and refluxed for 30 minutes till brown fumes were produced. The process of adding $5 \mathrm{~mL}$ of concentrated $\mathrm{HNO}_{3}$ was repeated over and over till white fumes appeared. The solution was vaporized to about $5 \mathrm{~mL}$ on mantle set at $95^{\circ} \mathrm{C}$ with a watch glass over it. After cooling the resulting sample, $2 \mathrm{~mL}$ of $\mathrm{H}_{2} \mathrm{O}$ and $3 \mathrm{~mL}$ of $30 \% \mathrm{H}_{2} \mathrm{O}_{2}$ were added and the solution was placed on the heating mantle to start the oxidation of peroxide until effervescence subsided. The vessel was cooled and the acid-peroxide digestate heated to about $5 \mathrm{~mL}$ at $95^{\circ} \mathrm{C}$. Later, addition of $10 \mathrm{~mL}$ concentrated $\mathrm{HCl}$ to the sample digest was done and the solution was placed on the heating source and refluxed for 15 minutes at $95^{\circ} \mathrm{C}$. The digested soil samples were analyzed for the heavy metals ( $\mathrm{Fe}, \mathrm{Pb}, \mathrm{Cu}, \mathrm{Cd}, \mathrm{Cr}, \mathrm{Ni}$, and $\mathrm{As}$ ) using atomic absorption spectrophotometer, Finally, the digestate was filtered and the filtrate collected for analysis of heavy metals in the Atomic Absorption Spectrophotometer (AAS, Perkin Elmer 2380). The AAS was fitted with specific lamp of a particular heavy metal, while the other conditions were the same as explained earlier (Welz \& Sperling, 1999). Blanks were prepared to check for background contamination by the reagents used.

\subsection{Data Analysis}

- The Azuka Index was used to determine the safe limits of each metal in the various study stations.

$\mathrm{Ai}=\mathrm{M}_{\mathrm{ch}} / \mathrm{M}_{\mathrm{cc}}$

$A_{i}=$ Azuka Safe Index for heavy metals; $M_{c h}=$ heavy metal mean concentration in the study station; $\mathbf{M}_{\mathrm{cc}}=$ Heavy metal mean control concentration for the station

Interpretation: $[<1=$ safe condition; $>1=$ Risk zone; $1=$ moderate risk $]$

- $\%$ Variation $=100(\mathrm{H} 2-\mathrm{H} 1) / \mathrm{H} 2$

[H2-Highest mean metal value; H1-Lowest mean metal value] 
- $\quad[\mathrm{M} 3 / \mathrm{M} 4=$ Mile 3/ Mile 4 variation; M3/RSU= Mile 3/ RSU variation; M4/RSU-Mile 4/RSU variations]

Table1. Heavy Metals Concentrations in Soil Samples from Mile 3

\begin{tabular}{|c|c|c|c|c|}
\hline \multirow{2}{*}{$\begin{array}{l}\text { Heavy metals } \\
(\mathrm{Mg} / \mathrm{Kg})\end{array}$} & \multicolumn{4}{|c|}{ Stations } \\
\hline & $\mathrm{Ta}$ & $\mathrm{Tb}$ & $\mathrm{Tc}$ & Control RSU \\
\hline $\mathrm{Fe}$ & $1,418.303 \pm 0.000$ & $1,418.301 \pm 0.001$ & $1,418.305 \pm 0.001$ & $890.453 \pm 373$ \\
\hline $\mathrm{Pb}$ & $7.650 \pm 0.000$ & $7.648 \pm 0.000$ & $7.649 \pm 0.000$ & $5.603 \pm 1.450$ \\
\hline $\mathrm{Cu}$ & $8.779 \pm 0.000$ & $8.777 \pm 0.000$ & $8.778 \pm 0.000$ & $7.589 \pm 0.840$ \\
\hline $\mathrm{Cd}$ & $2.691 \pm 0.000$ & $2.693 \pm 0.000$ & $2.692 \pm 0.000$ & $0.169 \pm 1.780$ \\
\hline $\mathrm{Cr}$ & $9.379 \pm 0.000$ & $9.380 \pm 0.000$ & $9.375 \pm 0.000$ & $3.428 \pm 4.210$ \\
\hline $\mathrm{Ni}$ & $7.414 \pm 0.000$ & $7.410 \pm 0.000$ & $7.409 \pm 0.000$ & $2.306 \pm 3.610$ \\
\hline As & $3.704 \pm 0.000$ & $3.706 \pm 0.000$ & $3.705 \pm 0.000$ & $0.703 \pm 2.120$ \\
\hline
\end{tabular}

Table2. Heavy Metal Concentrations in Soil Samples from Kala (Mile 4) Study Station

\begin{tabular}{|c|c|c|c|c|}
\hline \multirow{2}{*}{$\begin{array}{c}\text { Heavy metals } \\
(\mathrm{Mg} / \mathrm{Kg})\end{array}$} & $\mathrm{Ta}$ & $\mathrm{Tb}$ & Stations \\
\cline { 2 - 5 } & $1,160.011 \pm 1.410$ & $1,164.012 \pm 1.410$ & $1,162.010 \pm 0.001$ & Control RSU \\
\hline $\mathrm{Fe}$ & $7.370 \pm 0.000$ & $7.374 \pm 0.000$ & $7.372 \pm 0.000$ & $5.603 \pm 1.250$ \\
\hline $\mathrm{Pb}$ & $5.842 \pm 0.000$ & $5.840 \pm 0.000$ & $5.844 \pm 0.000$ & $7.589 \pm 1.240$ \\
\hline $\mathrm{Cu}$ & $1.434 \pm 0.000$ & $1.436 \pm 0.000$ & $1.438 \pm 0.000$ & $0.169 \pm 0.900$ \\
\hline $\mathrm{Cd}$ & $6.486 \pm 0.000$ & $6.489 \pm 0.000$ & $6.492 \pm 0.000$ & $3.428 \pm 2.160$ \\
\hline $\mathrm{Cr}$ & $5.382 \pm 0.000$ & $5.386 \pm 0.000$ & $5.384 \pm 0.000$ & $2.306 \pm 2.180$ \\
\hline $\mathrm{Ni}$ & $1.893 \pm 0.000$ & $1.890 \pm 0.000$ & $1.896 \pm 0.000$ & $0.703 \pm 0.840$ \\
\hline $\mathrm{As}$ &
\end{tabular}

Table3. Heavy Metals Concentrations in Soil Samples from RSU Control Station

\begin{tabular}{|c|c|c|c|c|}
\hline \multirow{2}{*}{$\begin{array}{c}\text { Heavy metals } \\
(\mathrm{Mg} / \mathrm{Kg})\end{array}$} & \multicolumn{3}{|c|}{ Stations } \\
\cline { 2 - 5 } & $\mathrm{Ta}$ & $\mathrm{Tb}$ & $\mathrm{Tc}$ & Control RSU \\
\hline $\mathrm{Fe}$ & $890.450 \pm 0.000$ & $890.452 \pm 0.000$ & $890.453 \pm 0.000$ & $930.362 \pm 28.220$ \\
\hline $\mathrm{Pb}$ & $5.603 \pm 0.000$ & $5.600 \pm 0.000$ & $5.606 \pm 0.000$ & $6.714 \pm 0.790$ \\
\hline $\mathrm{Cu}$ & $7.589 \pm 0.000$ & $7.589 \pm 0.000$ & $7.589 \pm 0.000$ & $8.572 \pm 0.700$ \\
\hline $\mathrm{Cd}$ & $0.169 \pm 0.000$ & $0.170 \pm 0.000$ & $0.168 \pm 0.000$ & $1.373 \pm 0.850$ \\
\hline $\mathrm{Cr}$ & $3.428 \pm 0.000$ & $3.425 \pm 0.000$ & $3.431 \pm 0.000$ & $5.433 \pm 1.420$ \\
\hline $\mathrm{Ni}$ & $2.304 \pm 0.000$ & $2.306 \pm 0.000$ & $2.308 \pm 0.000$ & $3.272 \pm 0.680$ \\
\hline $\mathrm{As}$ & $0.703 \pm 0.000$ & $0.700 \pm 0.000$ & $0.706 \pm 0.000$ & $1.630 \pm 0.660$ \\
\hline
\end{tabular}

Table4. Spatial Variation of Heavy Metals Concentrations in Soil Samples from Mile 3, Mile 4 and RSU Study Stations

\begin{tabular}{|c|c|c|c|c|}
\hline \multirow{2}{*}{$\begin{array}{c}\text { Heavy metals } \\
(\mathrm{Mg} / \mathrm{Kg})\end{array}$} & \multicolumn{3}{|c|}{ Stations } \\
\cline { 2 - 5 } & Mile 4 & Mile 3 & RSU & Mean \\
\hline $\mathrm{Fe}$ & $1,162.011 \pm 3.600$ & $1,418.303 \pm 184$ & $890.453 \pm 188$ & 1156.922 \\
\hline $\mathrm{Pb}$ & $7.372 \pm 0.350$ & $7.649 \pm 0.550$ & $5.603 \pm 0.900$ & 6.875 \\
\hline $\mathrm{Cu}$ & $5.842 \pm 1.100$ & $8.778 \pm 0.970$ & $7.589 \pm 0.130$ & 7.403 \\
\hline $\mathrm{Cd}$ & $1.436 \pm 0.000$ & $2.692 \pm 0.890$ & $0.169 \pm 0.000$ & 1.432 \\
\hline $\mathrm{Cr}$ & $6.489 \pm 0.030$ & $9.378 \pm 1.470$ & $3.428 \pm 1.500$ & 6.432 \\
\hline $\mathrm{Ni}$ & $5.384 \pm 0.180$ & $7.412 \pm 1.190$ & $2.306 \pm 1.360$ & 5.034 \\
\hline $\mathrm{As}$ & $1.893 \pm 0.100$ & $3.705 \pm 0.800$ & $0.703 \pm 0.700$ & 2.100 \\
\hline
\end{tabular}

Table5. Percentage Variation of Heavy Metals in Soils of Study Areas

\begin{tabular}{|c|c|c|c|}
\hline \multirow{2}{*}{ Heavy metals $\%$} & \multicolumn{3}{|c|}{ Stations } \\
\cline { 2 - 4 } & $\mathrm{M}_{3} / \mathrm{M}_{4}$ & $\mathrm{M}_{3} / \mathrm{RSU}$ & $\mathrm{M} 4 / \mathrm{RSU}$ \\
\hline $\mathrm{Fe}$ & 18.07 & 79.02 & 23.37 \\
\hline $\mathrm{Pb}$ & 3.62 & 26.75 & 24.00 \\
\hline $\mathrm{Cu}$ & 33.45 & 13.55 & 23.02 \\
\hline $\mathrm{Cd}$ & 46.65 & 93.72 & 88.23 \\
\hline $\mathrm{Cr}$ & 30.81 & 63.45 & 56.85 \\
\hline $\mathrm{Ni}$ & 27.36 & 68.89 & 57.17 \\
\hline $\mathrm{As}$ & 48.91 & 81.02 & 62.86 \\
\hline
\end{tabular}


Table6. WHO Standard Permissible Limits for Heavy Metals

\begin{tabular}{|c|c|c|}
\hline Elements & $\begin{array}{c}* \text { Target value of soil } \\
(\mathbf{m g} / \mathbf{k g})\end{array}$ & $\begin{array}{c}* * \text { Permissible value of plant } \\
(\mathbf{m g} / \mathbf{k g})\end{array}$ \\
\hline $\mathrm{Cd}$ & 0.8 & 0.02 \\
\hline $\mathrm{Zn}$ & 50 & 0.60 \\
\hline $\mathrm{Cu}$ & 36 & 10 \\
\hline $\mathrm{Cr}$ & 100 & 1.30 \\
\hline $\mathrm{Pb}$ & 85 & 2 \\
\hline $\mathrm{Ni}$ & 35 & 10 \\
\hline
\end{tabular}

*Target values are specified to indicate desirable maximum levels of elements in unpolluted soils. Source: Denneman and Robberse 1990; Ministry of Housing, Netherlands 1994 and **Source: WHO (1996)

Table7. Safe Limits of Heavy Metals in Soils of Study Areas

\begin{tabular}{|c|c|c|c|}
\hline Heavy metals \% & \multicolumn{3}{|c|}{ Stations } \\
\cline { 2 - 4 } & $\mathrm{M}_{3}$ & $\mathrm{M}_{4}$ & RSU \\
\hline $\mathrm{Fe}$ & 1.59 & 1.30 & 1 \\
\hline $\mathrm{Pb}$ & 1.36 & 1.31 & 1 \\
\hline $\mathrm{Cu}$ & 1.16 & 0.77 & 1 \\
\hline $\mathrm{Cd}$ & 15.93 & 8.50 & 1 \\
\hline $\mathrm{Cr}$ & 2.74 & 1.90 & 1 \\
\hline $\mathrm{Ni}$ & 3.21 & 2.33 & 1 \\
\hline $\mathrm{As}$ & 5.27 & 2.69 & 1 \\
\hline
\end{tabular}

\section{DISCUSSION OF FINDINGS}

\subsection{Concentration of Iron $(\mathrm{Fe})$}

The concentrations of $\mathrm{Fe}(\mathrm{mg} / \mathrm{Kg})$ in the Mile 3 station were $1,418.303 \pm 0.000,1418.301 \pm 0.001$, $1418.305 \pm 0.001$ for $\mathrm{Ta}, \mathrm{Tb}, \mathrm{Tc}$ and mean of $1,418.303 \pm 184$ respectively. The control station of RSU was $890.453 \pm 373$. Similarly, the Mile 4 study station recorded for Ta, Tb, Tc as $1,160.011$ $\pm 1.410,1164.012 \pm 1.410$, and $1162.010 \pm 0.001$ while the mean concentration was $1,162.011 \pm$ 3.600 respectively. The control station of RSU recorded $\mathrm{Fe}$ concentrations of $\mathrm{Ta}, \mathrm{Tb}, \mathrm{Tc}$ as 890.450 $\pm 0.000,890.452 \pm 0.000,890.453 \pm 0.000$ while the mean concentration was $890.453 \pm 188$ respectively.

Thus, these findings suggest that the studied soil sample is severely contaminated by the Iron metal. The high observed Fe levels could be attributed to the nature of the parental material of soils in the study site (Sharma et al., 2008). Iron (Fe) is an element relatively abundant in many cultivated soils with an average total concentration of 20 to $40 \mathrm{~g} \mathrm{~kg}^{-1}$ (Cornell \& Schwertmann, 2003). Research has shown that Iron (Fe) plays significant roles in plant physiology (Buchauer, 1973; Demirezen \& Aksoy, 2006). The result from this study corroborates with those of similar researches confirming the high Fe content of the soil as they were higher than the FEPA maximum permissive limits (Mohammed \& Folorunsho, 2015; Sahu, \& Kacholi, 2016).

Comparatively, the mile 3 study stations (is of more human impact) showed results higher than those at the mile 4 but lower than those from the control station where conventional human activities are less in terms of business environment. This result can be attributed to the nature of anthropogenic inputs and soil structure, texture and parent rock prevalent around the study stations but most importantly by the nature of the parent material composition (Sahu, \& Kacholi, 2016). This is verified by the percentage variations between the study stations, $\mathrm{M}_{3} / \mathrm{M}_{4}, \mathrm{M}_{3} / \mathrm{RSU}$ and $\mathrm{M}_{4} / \mathrm{RSU}$ as 18.07, 79.02 and 23.37 respectively and shown in Table 5. Most studies on heavy metals in soils were linked to common industrial, agricultural and human activities and which are not rife here (Ogedengbe \& Akinbile, 2004; Tasrina et al, 2015).

The safety index $\left(\mathrm{A}_{\mathrm{i}}\right)$ as in Table 7 shows that the Mile 3 study station was more polluted by increased concentration of $\mathrm{Fe}$ as it exceeded the safety limit of less than 1. Though the Niger Delta soils have high concentration of $\mathrm{Fe}$, this must be checked to avoid deleterious effects on plants and animals including man as supported by Edet et al. (2014) in similar studies. 


\subsection{Concentration of $\mathbf{P b}$}

Mile 3 study station recorded concentrations for $\mathrm{Pb}(\mathrm{mg} / \mathrm{Kg})$ in $\mathrm{Ta}, \mathrm{Tb}, \mathrm{Tc}$ as $7.370 \pm 0.000,7.374$ $\pm 0.000,7.372 \pm 0.000$ and $7.649 \pm 0.550$ as mean respectively. Similarly, Mile 4 study station recorded $\mathrm{Pb}$ concentrations of $7.370 \pm 0.000, \quad 7.374 \pm 0.000,7.372 \pm 0.000$ and mean value of 7.372 \pm 0.350 respectively. The control station of RSU recorded $\mathrm{Pb}$ concentrations of $\mathrm{Ta}, \mathrm{Tb}, \mathrm{Tc}$ as 5.603 $\pm 0.000,5.600 \pm 0.000$, and $5.606 \pm 0.000$ while the mean concentration was $5.603 \pm 0.900$ respectively.

The concentration of $\mathrm{Pb}$ followed similar trend as they were higher than the WHO permissible limits $(1.6 \mathrm{mg} / \mathrm{Kg})$ and higher than those obtained in Kaduna soil (Mohammed \& Folorunsho, 2015). Similarly, $\mathrm{Pb}$ concentration was higher at the mile 3 study station but lowest at the control (RSU). This may be attributed to the high vehicular traffic, road runoff around the mile 3 axis compared to mile 4 , whereas almost negligible at the RSU control station as supported by Kananke et al. (2014) and Tasrina et al. (2015) in similar studies. The concentration of Pb though lower than WHO (1996) standard was higher than FEPA standard (Now ministry of Environment, Nigeria). The percentage variation in the concentration of $\mathrm{Pb}$ by $\mathrm{M}_{3} / \mathrm{M}_{4}, \mathrm{M}_{3} / \mathrm{RSU}$ and $\mathrm{M}_{4} / \mathrm{RSU}$ are 3.62, 26.75 and 24.00 respectively, showing lower significant impacts (Table 5).

Heavy metals pollution in soil has a lot of negative impacts, hence, of great concern to public health, agricultural production, and environmental health (Fergusson, 1990; Ma et al., 1994; Goyer, 1997). The soil pollution is mainly due to disposal of industrial and urban wastes as well as usage of agrochemicals (McBride, 2003; Demirezen \& Aksoy, 2006). Lead (Pb) remains one of the highly toxic metals in soils and stems from surrounding traffic activities and agrochemicals applications (Kananke et al., 2014).

The safety index $\left(\mathrm{A}_{\mathrm{i}}\right)$ as in Table 7 showed that the Mile 3 study station was slightly more polluted by increased concentration of $\mathrm{Pb}$ as it exceeded the safety limit of less than 1 . Though the Niger Delta soils have high impact of $\mathrm{Pb}$ due to prevailing anthropic activities, this must be checked to avoid deleterious effects on plants and animals including man as supported by Edet, et al. (2014) and Tsuwang, et al. (2014) in Northwestern Nigeria.

\subsection{Concentration of $\mathrm{Cu}$}

Mile 3 study station recorded concentrations for $\mathrm{Cu}(\mathrm{mg} / \mathrm{Kg})$ in $\mathrm{Ta}, \mathrm{Tb}, \mathrm{Tc}$ as $8.779 \pm 0.000,8.777$ $\pm 0.000,8.778 \pm 0.000$ and $8.778 \pm 0.970$ as mean respectively. Similarly, Mile 4 study station recorded $\mathrm{Cu}$ concentrations of $5.842 \pm 1.100,8.778 \pm 0.970, \quad 7.589 \pm 0.130$ and mean value of $5.842 \pm 1.100$ respectively. The control station of RSU recorded $\mathrm{Cu}$ concentrations of $\mathrm{Ta}, \mathrm{Tb}, \mathrm{Tc}$ as $7.589 \pm 0.000,7.589 \pm 0.000,7.589 \pm 0.000$ while the mean concentration was $7.589 \pm 0.130$ respectively.

The level of $\mathrm{Cu}$ in the study stations showed relatively lower values compared to permissible standard limits (FEPA, WHO/ UNEP, 1997). The mean concentrations of copper recorded were below the WHO/FAO (2001) permissible limit of $100 \mathrm{mg} / \mathrm{kg}$ for soils. These values were lower than those obtained by Mohammed and Folorunsho (2015) in Kaduna, Central Nigeria. The trend of percentage variation, $\mathrm{M}_{3} / \mathrm{M}_{4}, \mathrm{M}_{3} / \mathrm{RSU}$ and $\mathrm{M}_{4} / \mathrm{RSU}$ were $33.45,13.55$ and 23.02 respectively. This showed that the difference between the both study stations was high showing parent material and anthropogenic effects were influential (Tasrina et al., 2015). This relatively lower concentration recorded is in tandem with those of Sahu and Kacholi (2016) in related studies. Increased concentration of $\mathrm{Cu}$ in soils causes decreases in enzymatic action especially earthworms which increases proper aeration for plant growth (Malley et al., 2006).

Badilla-Ohlbaum et al. (2001) recorded higher soil $\mathrm{Cu}$ contents in Chile. Cultivation may cause soil contamination by heavy metals, specifically copper in vineyard areas (Facchinelli et al., 2001; Nachtigall et al., 2007; Fernandez-Calviño et al., 2009). The intensive use of agrochemicals with $\mathrm{Cu}$ in their composition may pollute the soil (Ramos \& López-Acevedo, 2004; Gaw et al., 2006; Komárek et al., 2010).

The safety index $\left(\mathrm{A}_{\mathrm{i}}\right)$ as in Table 7 showed that the Mile 3 study station was also more polluted by increased concentration of $\mathrm{Cu}$ as it exceeded the safety limit $(<1)$ whereas the Mile 4 station had $\mathrm{A}_{\mathrm{i}}$ of 0.77 which showed a good safe limit condition. Though some Niger Delta soils have high concentration of $\mathrm{Pb}$, this must be checked to avoid deleterious effects on plants and animals including man as supported by Edet, et al. (2014) in similar studies. 


\subsection{Concentration of $\mathrm{Cd}$}

Mile 3 study station recorded concentrations for $\mathrm{Cd}(\mathrm{mg} / \mathrm{Kg})$ in $\mathrm{Ta}, \mathrm{Tb}, \mathrm{Tc}$ as $2.691 \pm 0.000,2.693$ $\pm 0.000,2.692 \pm 0.000$ and $2.692 \pm 0.890$ as mean respectively. Similarly, Mile 4 study station recorded Cd concentrations of $1.434 \pm 0.000,1.436 \pm 0.000,1.438 \pm 0.000$ and mean value of 1.436 \pm 0.000 respectively. The control station of RSU recorded Cd concentrations of Ta, $\mathrm{Tb}, \mathrm{Tc}$ as 0.169 $\pm 0.000,0.170 \pm 0.000,0.168 \pm 0.000$ while the mean concentration was $0.169 \pm 0.000$ respectively.

The concentration of $\mathrm{Cd}$ in the study stations were above the permissible limits and hence needs adequate monitoring (WHO, 1996). The results for Cd in the RSU control station was within the permissible limit showing that not much of anthropogenic inputs (WHO/FAO, 2007). The Cd concentrations were found in excess of FAO/WHO recommended limits, respectively, this indicates potential health risk for human through the food chain (Okunola et al., 2008). The concentration of $\mathrm{Cd}$ in the Mile 3 and Mile 4 stations fall within similar range with earlier researches (Okunola et al., 2008).

The percentage variation (\%) of $\mathrm{M}_{3} / \mathrm{M}_{4}, \mathrm{M}_{3} / \mathrm{RSU}$ and $\mathrm{M}_{4} / \mathrm{RSU}$ were $46.65,93.72$ and 88.23 respectively. The values showed that there is high impact of activities within the $\mathrm{M}_{3}$ and $\mathrm{M}_{4}$ study areas as that of RSU was relatively low. This high percentage variation of study stations from the control is a great threat to human health as Cd can lead to so many health challenges. Researches have shown that metal pollutants can be harmful to roadside vegetation, wildlife and the neighboring human settlements (Turer \& Maynard, 2003; Awofolu, 2005). Cadmium (Cd) concentrations were found in excess of FAO/WHO recommended limits which could be due to the nature of $\mathrm{Cd}$, since $\mathrm{Cd}$ is known to be less retained by the soil than other toxic cations (Lokeshwari \& Chandrappa, 2006) or the low organic matter contents of soils sampled could have also enhanced soil retention of metals (Okunola et al., 2008).

However, considerably higher concentrations of Cd were detected when compared to $0.2 \mathrm{mg} \mathrm{kg}{ }^{-1}$ (WHO/FAO, 2001) maximum critical limit above which toxicity is possible. Cadmium (Cd) showed higher concentration levels of contamination in the study areas than several mean values obtained in similar researches (Ndiokwere, 1984; Ho \& Tai, 1988; Jaradat \& Momani, 1999). The concentrations of Cd obtained in this study is far higher than earlier research result of $0.004 \mathrm{mg} / \mathrm{Kg}$, which showed that anthropogenic inputs must be well monitored (Muyoma et al., 2019).

The safety index $\left(\mathrm{A}_{\mathrm{i}}\right)$ as in Table 7 shows that the Mile 3 study station was highly polluted as compared to the Mile 4 but both exceeded the safe limit $(<1)$ by increased concentration of $\mathrm{Cd}$. Though the Niger Delta soils have low concentration of $\mathrm{Cd}$, this result showed a dangerous trend which must be checked to avoid deleterious effects on plants and animals (Edet, et al., 2014; Ideriah et al., 2005).

\subsection{Concentration of $\mathrm{Cr}$}

Mile 3 study station recorded concentrations for $\mathrm{Cr}(\mathrm{Mg} / \mathrm{Kg})$ in $\mathrm{Ta}, \mathrm{Tb}, \mathrm{Tc}$ as $9.379 \pm 0.000,9.380$ $\pm 0.000,9.375 \pm 0.000$ with mean of $9.378 \pm 1.470$ respectively. Similarly, Mile 4 study station recorded Cr concentrations of $6.486 \pm 0.000,6.489 \pm 0.000,6.492 \pm 0.000$ and mean value of 3.428 \pm 2.160 respectively. The control station of RSU recorded $\mathrm{Cr}$ concentrations of $\mathrm{Ta}, \mathrm{Tb}, \mathrm{Tc}$ as 3.428 $\pm 0.000,3.425 \pm 0.000$, and $3.431 \pm 0.000$ while the mean concentration was $3.428 \pm 1.500$ respectively.

The concentration of $\mathrm{Cr}$ in the $\mathrm{M}_{3}$ study station $(9.378 \pm 0.000)$ showed that of relatively higher value than the control $(3.428 \pm 4.21)$. Similarly, the $\mathrm{M}_{4}$ study station had a lower concentration of $6.489 \pm 0.000$ showing that the soil of $\mathrm{M}_{3}$ is more contaminated with $\mathrm{Cr}$. The concentration of $\mathrm{Cr}$ in the RSU study station is an indication of lower pollution potential as it is lower than the WHO/FAO (2007) permissible limit of $5.00-30.00 \mathrm{mg} / \mathrm{kg}$. Results from this study indicated that concentration value of $\mathrm{Cr}$ in the soil samples were generally higher than the FEPA maximum permissive limits but lower than WHO (1996) for plants and soil. Heavy metals such as Cr are exceptionally toxic and dangerous environmental pollutants (Buchauer, 1973; McBride, 2003). The percentage variations (\%) showed that $\mathrm{M}_{3} / \mathrm{M}_{4}, \mathrm{M}_{3} / \mathrm{RSU}$ and $\mathrm{M}_{4} / \mathrm{RSU}$ were $30.81,63.45$ and 56.85 respectively. This means that the input to parent material from human activities for the $\mathrm{M}_{3}$ study station is higher indicating that it has more human activities and impacts. 
The concentration of chromium $\mathrm{Cr}$ ranged from $6.486-6.492 \mathrm{mg} / \mathrm{kg}$ at $\mathrm{M}_{4}$ and $9.375-9.380 \mathrm{mg} / \mathrm{Kg}$ at $\mathrm{M}_{3}$ with mean values 6.489 and $9.378 \mathrm{mg} / \mathrm{Kg}$ respectively. The high concentration of $\mathrm{Cr}$ recorded could be as a result of the recycling of e-waste such as used computers, cables, printers, photocopy machines and batteries at the sites. The absence of these wastes at the control station could have been the cause of lower concentrations of Cd around the RSU station. Adverse health effects associated with $\mathrm{Cr}$ (VI) exposure include occupational asthma, eye irritation and damage, perforated eardrums, respiratory irritation, kidney damage, liver damage, pulmonary congestion and edema, upper abdominal pain, nose irritation and damage, respiratory cancer, and skin irritation (Dayan \& Paine, 2001). When inhaled, chromium compounds cause respiratory tract irritations and pulmonary sensitization. Chronic inhalation of $\mathrm{Cr}(\mathrm{VI})$ compounds increases the risk of lung, nasal, and sinus cancer. Severe dermatitis and usually painless skin ulcers can result from contact with $\mathrm{Cr}$ (VI) compounds. The concentration of $\mathrm{Cr}$ in the soils may vary considerably according to the natural composition of rocks and sediments that compose them (Kimbrough et al, 1999). The levels of chromium in the soil may increase mainly through anthropogenic deposition, as for example atmospheric deposition (Rosas et al., 1989).

The safety index $\left(A_{i}\right)$ as in Table 7 shows that the Mile 3 study station $\left(A_{i}=2.74\right)$ was more polluted by increased concentration of $\mathrm{Cr}$ as it exceeded the safety limit $(<1)$. Though the Niger Delt a soils have high concentration of $\mathrm{Cr}$ in certain areas, this must be checked to avoid deleterious effects on terrestrial organisms (Ideriah, et al. 2005; Edet, et al., 2014).

\subsection{Concentration of $\mathrm{Ni}$}

Mile 3 study station recorded concentrations for $\mathrm{Ni}(\mathrm{mg} / \mathrm{Kg})$ in $\mathrm{Ta}, \mathrm{Tb}, \mathrm{Tc}$ as $7.414 \pm 0.000,7.410$ $\pm 0.000,7.409 \pm 0.000$ with mean of $7.412 \pm 1.190$ respectively. Similarly, Mile 4 study station recorded Ni concentrations of $5.382 \pm 0.000,5.386 \pm 0.000,5.384 \pm 0.000$ and mean value of 5.384 \pm 0.180 respectively. The control station of RSU recorded Ni concentrations of Ta, Tb, Tc as 2.304 \pm $0.000,2.306 \pm 0.000,2.308 \pm 0.000$ while the mean concentration was $2.306 \pm 1.360$ respectively.

The percentage variations (\%) for $\mathrm{M}_{3} / \mathrm{M}_{4}, \mathrm{M}_{3} / \mathrm{RSU}, \mathrm{M}_{4} / \mathrm{RSU}$ study relationship were 27.36, 68.89, and 57.17 respectively. This showed that there was high input from human activities at the $\mathrm{M}_{3} / \mathrm{RSU}$ which much be monitored to avoid Ni poisoning. The $\mathrm{M}_{3}$ study station recorded the highest concentration of $\mathrm{Ni}$ as supported by the level of anthropogenic activities around the study locations such as mechanics, sales of old fridges (Belgium fridges) and wastes dumps. The poor drainage cum flooding situation around the study sites exposes it to potential of Ni availability. Though the concentration of Ni was lower than WHO (1996) permissible limit (35 mg/Kg) for plants and soils, it was found to relatively higher than WHO/FAO (2007) permissible limit for edible plant of $1.67 \mathrm{mg} / \mathrm{Kg}$ and other standards (WHO, 1971; DPR, 1991; FEPA, 1991). This showed that there is a considerable increase in the amount of $\mathrm{Ni}$ available in the study sites. This abrupt rise in $\mathrm{Ni}$ concentration is a threat to plants to which humans depend on for livelihood hence effect on health of humans. Plants such as vegetables which are regular consumables are polluted by heavy metals like Ni both in soil and water and so pose a serious threat to public and environmental health and agricultural production (Fergusson, 1990; Ma et al., 1994; Goyer, 1997). The concentration of Ni recorded in this study is below that observed in similar research in Kaduna (Inuwa et al., 2007). Heavy metals pollution of the soil is caused by various metals especially $\mathrm{Ni}$ and many others (Karaca et al., 2010).

The safety index $\left(\mathrm{A}_{\mathrm{i}}\right)$ as in Table 7 showed that the Mile 3 study station was more polluted by increased concentration of $\mathrm{Ni}$ as it exceeded the safety limit $(<1)$. Though the Niger Delta soils have relatively low concentration of $\mathrm{Ni}$, this result is a threat and so must be checked to avoid negative effects (Iwegbue et al., 2006).

\subsection{Concentration of As}

Mile 3 study station recorded concentrations for $\mathrm{As}(\mathrm{Mg} / \mathrm{Kg})$ in $\mathrm{Ta}, \mathrm{Tb}, \mathrm{Tc}$ as $3.704 \pm 0.000,3.706$ $\pm 0.000,3.705 \pm 0.000$ with mean of $3.705 \pm 0.800$ respectively. Similarly, Mile 4 study station recorded As concentrations of $1.893 \pm 0.000,1.890 \pm 0.000,1.896 \pm 0.000$ and mean value of 1.893 \pm 0.100 respectively. The control station of RSU recorded As concentrations of $\mathrm{Ta}, \mathrm{Tb}, \mathrm{Tc}$ as 0.703 $\pm 0.000,0.700 \pm 0.000,0.706 \pm 0.000$ while the mean concentration was $0.703 \pm 0.700$ respectively as shown in Table 5 . 
The percentage variations (\%) for $\mathrm{M}_{3} / \mathrm{M}_{4}, \mathrm{M}_{3} / \mathrm{RSU}, \mathrm{M}_{4} / \mathrm{RSU}$ study relationship were $48.91,81.02$ and 62.86 respectively. The concentrations obtained were lower than those obtained in soils of Anka area of Northwestern Nigeria (Tsuwang et al., 2014). This result showed a high difference in the concentrations between the study stations and the control (RSU). This is a clear indication of high anthropogenic inputs and activities which may also be facilitated by parent materials of the study locations. Arsenic (As) is one of the very toxic metals in nature whose concentration must be periodically monitored. This is because heavy metals are potent enzyme inhibitors to which man cannot ignore and the uptake of heavy metals by plants and subsequent accumulation along the food chain is a potential threat to animal and human health. (Singh \& Kalamdhad, 2011; Mustafa $\&$ Alsharif, 2018). Low concentration of heavy metals may inhibit the physiological metabolism of plants (Singh \& Kalamdhad, 2011). Heavy metals exert toxic effects on soil microorganism hence leads to variations in diversity, population size and overall activity of the soil microbial communities (Ashraf \& Ali, 2007). Arsenic is a natural component of the earth's crust and is widely distributed throughout the environment in the air, water and land. It is highly toxic in its inorganic form.

Inorganic arsenic is a confirmed carcinogen and is the most significant chemical contaminant in drinking-water globally. Arsenic can also occur in an organic form. Inorganic arsenic compounds (such as those found in water) are highly toxic while organic arsenic compounds (such as those found in seafood) are less harmful to health. Arsenic has both acute and chronic effects and WHO provisional guideline value of $10 \mu \mathrm{g} / \mathrm{L}$ were not exceeded but arsenic poisoning must be monitored since it is natural component of the earth crust (Ravenscroft et al., 2009).

Research has shown that Arsenic (As) background concentrations in soil range from 1 to $40 \mathrm{mg} / \mathrm{Kg}$, with mean values often around $5 \mathrm{mg} / \mathrm{Kg}$. Naturally elevated levels of arsenic in soils may be associated with geological substrata such as sulfide ores (IPCS, 1981). Anthropogenic inputs in contaminated soils can have concentrations of arsenic up to several grams per $100 \mathrm{ml}$. Arsenic (As) from weathered rock and soil may be transported by wind or water erosion. However, as many arsenic compounds tend to adsorb to soils, leaching usually occurs during transportation over only short distances in soil (Moore et al., 1988; Welch et al., 1988).

The safety index $\left(\mathrm{A}_{\mathrm{i}}\right)$ as in Table 7 showed that the Mile 3 study station was far contaminated by As from the increased concentration of $\mathrm{Ni}$ as it exceeded the safety limit $(<1)$. Though the Niger Delta soils have relatively low concentration of As, this result is a threat and so must be checked to avoid negative effects (Hughes et al., 1988; Iwegbue et al. (2006). This is because arsenic causes disquiet from ecological and personal points of view (Hughes et al., 1988).

\section{CONCLUSION}

This study showed that the Mile 3 subsoil is contaminated by heavy metals more than the Mile 4 and RSU study stations as their concentrations are relatively higher than permissible limits for soil. This was attributed mostly to underlying parent materials, composition and anthropogenic inputs due to the busy and occupational activities around these study sites (mostly $\mathbf{M}_{3}$ and $\mathbf{M}_{4}$ ). Heavy metals are naturally present in the soil but geologic and anthropogenic activities can increase their concentration to amounts that are may be toxic to living things which must be checked. High percentage variations occurred between the study stations and the control, $\mathrm{M}_{3} / \mathrm{RSU}$ for $\mathrm{Fe}, \mathrm{Cd}, \mathrm{Cr}$, $\mathrm{Ni}$, As and $\mathrm{M}_{4} / \mathrm{RSU}$ for $\mathrm{Cd}, \mathrm{Cr}, \mathrm{Ni}$, As respectively. Though, the result of the ANOVA showed pvalue of $0.2845(\alpha=0.05)$ meaning no significant difference within the $\mathrm{M}_{3}, \mathrm{M}_{4}$ and RSU stations was also corroborated by the t-test result for $\mathrm{M}_{3} / \mathrm{RSU}$ control and $\mathrm{M}_{4} / \mathrm{RSU}$ control which were 1.013 and 1.037 respectively at 0.05 significant levels.

\section{REFERENCES}

[1] Adamo, P., Arienzo, M., Bianco, M., Terribile, F.\& Violante, P. (2002). Heavy metal contamination of the soils used for stocking raw materials in the former ILVA iron-steel industrial plant of Bagnoli (southern Italy). Sci Total Environ 295:17-34.

[2] A dictionary of chemistry (2000). Oxford university press. Oxford reference [Online], Oxford University Press.

[3] Ashraf R. \& Ali T.A. (2007). Effect of heavy metals on soil microbial community and mung beans seed germination. Pakistan Journals of Botany, 39(2), 629-63. 
[4] ATSDR (2007). Agency for Toxic Substances and Disease Registry. Draft Toxicological Profile for Cadmium. Atlanta, GA: ATSDR.

[5] Awofolu, O.R., (2005). A survey of trace metals in vegetation, soil and lower animal along some selected major roads in metropolitan city of Lagos. Environ. Monit. Assess., 105: 431-447.

[6] Badilla-Ohlbaum,R., Ginocchio, R., Rodríguez, P.H., Céspedes, A., González,S., Allen, H.E. \& Gustavo E. L. (2001). Relationship between soil copper content and copper content of selected crop plants in central Chile. Journal of Environmental Toxicology and Chemistry, 20(12): 2749-2757.

[7] Buchauer, M.J. (1973). Contamination of soil and vegetation near a zinc smelter by zinc, cadmium, copper, and lead. Environmental Science \& Technology, 7 (2), 131-135.

[8] Chauhan, G. \& Chauhan, U.K. (2014). "Human health risk assessment of heavy metals via dietary intake of vegetables grown in wastewater irrigated area of Rewa, India," International Journal of Scientific Research and Publications, 4 (9): 1-9.

[9] Chronopoulos J., Haidouti C., Chronopoulou A. \& Massas, I. (1997). Variations in plant and soil lead and cadmium content in urban parks in Athens, Greece. Sci Total Environ. ,196:91- 8.

[10] Colombo, C., Palumbo, G., He, J. et al. (2014). Review on iron availability in soil: interaction of Fe minerals, plants, and microbes. J. Soils and Sediments 14, 538-548.

[11] Cornell, R.M. \& Schwertmann, U. (2003). The iron oxides, 2nd edn, Wiley-VCH, Weinheim.

[12] Csavina J., Field J., Taylor M. P., Gao S., Landázuri A., Betterton E. A., et al. (2012). A review on the mportance of metals and metalloids in atmospheric dust and aerosol from mining operations. Sci. Total Environ., 433C, 58-73. 10.1016/j.scitotenv.2012.06.013

[13] D'Amore, J.J., Al-Abed, S.R., Scheckel, K.G. \& Ryan, J.A. (2005)."Methods for speciation of metals in soils: a review," Journal of Environmental Quality, 34 (5): 1707-1745.

[14] Dayan, A.D. \& Paine, A.J. (2001) Mechanisms of chromium toxicity, carcinogenicity and allergenicity: review of the literature from 1985 to 2000. Hum Exp Toxicol. 20(9):439-451.

[15] Demirezen, D. \& Aksoy, A. (2006). "Heavy metal levels in vegetables in Turkey are within safe limits for $\mathrm{Cu}, \mathrm{Zn}, \mathrm{Ni}$ and exceeded for Cd and Pb.” Journal of Food Quality, 29(3): 252-265.

[16] DPR (1991). Department of Petroleum Resources. Environmental Guidelines and Standard for the Petroleum Industry in Nigeria. Lagos: Ministry of Petroleum.

[17] Duruibe, J.O., Ogwuegbu, M.D.C. \& Egwurugwu, J.N. (2007). Heavy metal pollution and human biotoxic effects," International Journal of Physical Sciences, 2 (5): 112-118.

[18] Edet, A., Ukpong, A.\& Nganje, T. (2014). The Concentration of Potentially Toxic Elements and Total Hydrocarbon in Soils of Niger Delta Region (Nigeria). Journal of Environment and Earth Science, 4(1):23-34.

[19] Edori, O.S. \& Iyama, W.A. (2017). Assessment of Physicochemical Parameters of Soils from Selected Abattoirs in Port Harcourt, Rivers State, Nigeria. Journal of Environmental Analytical Chemistry, 4 (3):194.

[20] Ernst E. (2002). Heavy metals in traditional Indian remedies. Eur J Clin Pharmacol. ,57 :891-6.

[21] Facchinelli, A., Sacchi, E.\& Mallen, L. (2001). Multivariate statistical and GIS-based approach to identify heavy metal sources in soils. Environmental Pollution, 114(3), 313-324.

[22] FEPA(1991).Federal Environmental Protection Agency. Guidelines and Standards for Environmental Pollution Control in Nigeria

[23] Fergusson, J.E. (1990). The Heavy Elements: Chemistry, Environmental Impact and Health Effects.Pergamin Press, Oxford, UK.

[24] Fernandez-Calviño, D., Nóvoa-Muñoz,J.C., Diaz-Raviña, M. \& Arias-Estévez, M.(2009). “Cooper accumulation and fractionation in vineyard soils from temperate humid zone (NWIberian Penninsula)," Geoderma, 153, (1-2): 119-129.

[25] Garrido, S., Campo, G.M.D., Esteller M.V., Vaca R. \& Lugo J. (2002). Heavy metals in soil treated with sewage sludge composting, their effect on yield and uptake of broad bean seeds (Vicia faba L.). Water, Air, and Soil Pollution, 166: 303-319.

[26] Gaw, S.K., Wilkins, A.L., Kim, N.D., Palmer,G.T. \& Robinson, P.(2006). Trace element and $\Sigma$ DDT concentrations in horticultural soils from the Tasman, Waikato and Auckland regions of New Zealand. Science of the Total Environment, 355(1-3):31-47.

[27] Goyer, R.A. (1997). "Toxic and essential metal interactions". Annual Review of Nutrition, 17, 37-50.

[28] Gupta, S., Jena, V. \& Jena, S. (2013). "Assessment of heavy metal contents of green leafy vegetables". Croatian Journal of Food Science and Technology, 5 (2): 53-60. 
[29] Gupta V. K., Singh S., Agrawal A., Siddiqi N. J., Sharma B. (2015a). Phytochemicals mediated remediation of neurotoxicity induced by heavy metals. Biochem. Res. Int. 2015:534769. 10.1155/2015/534769 [PMC free article] [PubMed] [CrossRef] [Google Scholar]

[30] Gupta V. K., Kumar A., Siddiqi N. J., Sharma B. (2015b). Rat brain acetyl cholinesterase as a biomarker of cadmium induced neurotoxicity. Open Access J. Tox. 1:555553.

[31] Halim, M., Conte, P. \& Piccolo, A. (2002). Potential availability of heavy metals to phytoextraction from contaminated soils induced by exogenous humic substances. Chemosphere, 52:26-75.

[32] Hinojosa, M. B., Carreira J. A., Ru1z, R.G., \& Dick, R.P. (2004). Soil moisture pre-treatment effects on enzyme activities as indicators of heavy metal-contaminated and reclaimed soils. Soil Biology \& Biochemistry, 36, 1559-1568.

[33] Ho, I.B. \& Tai, K.M. (1988). Elevated levels of lead and other metals in roadside soil and grass and their use to monitor aerial metal depositions in Hong Kong. Environ. Pollut., 49: 37-51.

[34] Hughes, J.P., Polissar, L. \& Van Belle, G. (1988). Evaluation and synthesis of health effects studiesof communities surrounding arsenic producing industries. Int J Epidemiol., 17:407-413.

[35] Ideriah, J.K.T., Umuaru, O.T.U. \& Adiukwu, U.P. (2005). Heavy Metal Contamination of Soils around Municipal Solid Waste Dump in Port Harcourt, Nigeria. Global Journal of Environmental Sciences, 4 (1): $1-4$.

[36] Inuwa, M., Abdulrahman , F.W., Birnin Yauri , U.A. \& Ibrahim , S.A.(2007). Analytical Assessment of Some Trace Metals in Soils Around the Major Industrial Areas of Northwestern Nigeria. Trends in Applied Science Research, 2(6): 515-521.

[37] IPCS (International Programme on Chemical Safety) (1981). Arsenic. Geneva, World Health Organization.

[38] Itai, T., Otsuka, M., Asante, K. A., Muto, M., Opoku-Ankomah, Y., Ansa-Asare, O. D., \& Tanabe, S. (2014). Variation and distribution of metals and metalloids in soil/ash mixtures from Agbogbloshie e-waste recycling site in Accra, Ghana. Science of the Total Environment, 470, 707-716.

[39] Iwegbue, C.M.A., Isirimah, N.O. \& Williams, E.S. (2006). Characteristics Levels of Heavy Metals in Soil Profiles of Automobile Mechanic Waste Dumps in Nigeria. Environmentalist, 26: 123-128.

[40] Iwegbue, C.M.A., Egobueze, E. \& Opuene, K. (2006). Preliminary assessment of heavy metals in level of soils of an oil field in the Niger Delta, Nigeria. International Journal of Environmental Science and Technology, 3(2):167-172.

[41] Jaradat, Q.M. \& Momani, A. (1999). Contamination of roadside soil plants and air with heavy metals in Jordan, A comparative study. Turk. J. Chem., 23: 209-220.

[42] Järup, L. (2003). Hazards of heavy metal contamination. Br Med Bull., 68 (1):167-182.

[43] Kabata-Pendias, A.\& Pendias, H. (2001). Trace Metals in Soils and Plants, 2nd edition. CRC Press, Boca Raton, Fla, USA.

[44] Kananke, T., Wansapala, J. \& Gunaratne, A. (2014). "Heavy Metal Contamination in Green LeafyVegetables Collected from Selected Market Sites of Piliyandala Area, Colombo District, Sri Lanka." American Journal of Food Science and Technology, 2 (5):139-144.

[45] Karaca A., Cetin, S.C., Turgay, O.C. \& Kizilkaya, R. (2010). Effects of Heavy Metals on Soil Enzyme Activities. In: I. Sherameti and A. Varma (Ed), Soil Heavy Metals, Soil Biology, Heidelberg 19, 237265.

[46] Kimbrough, D. E., Cohen, Y., Winer, A. M., Creelman, L. \& Mabuni, C. (1999). A critical assessment of chromium in the environment," Critical Reviews in Environmental Science and Technology, 29(1): 1-46.

[47] Komárek, M., Čadková, E., Chrastný, V., Bordas, Fand J. \& Bollinger, J. (2010). Contamination of vineyard soils with fungicides: a review of environmental and toxicological aspects." Environment International, 36, (1), 138-151.

[48] Lane, T.W. \& More,1. F.M. (2009). A biological function for cadmium in marine diatoms. Proc Natl Acad Sc., 462-31.

[49] Lane, T.W., Saito, M.A., George, G.N., Pickering, I.J., Prince, R.C. \& More, I. F. M. (2005). Biochemistry: A cadmium enzyme from a marine diatom. Nature, 435:42.

[50] Lim, S. R. S. J. (2010). Toxicity potentials from waste cellular phones, and a waste management policy integrating consumer, corporate, and government responsibilities. Waste Management, 30(8-9), 1653-1660.

[51] Lokeshwari, H. \& Chandrappa, G.T. (2006). Impact of heavy metal contamination of Bellandur lake on soil and cultivated vegetation. Curr. Sci., 91: 622-627.

[52] Long, X.X., Yang, X.E. \& Ni, W.Z. (2002). Current status and prospective on phytoremediation of heavy metal polluted soils. J Appl Ecol., 13:757-62. 
[53] Lubben, S. \& Sauerbeck, D. (1991). "The uptake and distribution of heavy metals by spring wheat," Water, Air, \& Soil Pollution, 57 (1): 239-247.

[54] Ma, Q.Y., Traina, S.J.,Logan, T.J. \& Ryan,J.A.(1994). "Effects of Aqueous Al, Cd, Cu, Fe(II), Ni, and Zn on Pb Immobilization by Hydroxyapatite. Environmental Science \& Technology, 28(7): 1219-1228.

[55] Malley C., Nair, J. \& Ho, G. (2006). Impact of heavy metals on enzymatic activity of substrate and on composting worms. Eisenia fetida. Bioresource Technology, 97: 1498-1502.

[56] McBride, M.B. (2003). Toxic metals in sewage sludge-amended soils: Has promotion of beneficial use discounted the risks?" Advances in Environmental Research, 8 (1), 5-19.

[57] Mcintyre T. (2003). Phytoremediation of heavy metals from soils. Adv Biochem Eng Biotechnol., 78:97123.

[58] Mohammed, S.A.\& Folorunsho, J.O. (2015). Heavy metal concentration in soil and Amaranthus retroflexus grown on irrigated farmlands in the Makera Area, Kaduna, Nigeria. Journal of Geography and Regional Planning, 8 (8): 210-217

[59] Moore J.N., Ficklin, W.H. \& Johns, C. (1988). Partitioning of arsenic and metals in reducing sulfidic sediments. Environ Sci Technol, 22(4): 432-437.

[60] Msaky, J.J. \& Calvet, R. (1990). Adsorption behavior of copper and zinc in soils: Influence of pH on adsorption characteristics," Soil Science, 150 (2): 513-522.

[61] Musee, N. (2011). Nanotechnology risk assessment from a waste management perspective: Are the current tools adequate? Human \& Experimental Toxicology, 30(8), 820-835.

[62] Mustafa, S.K. \& Alsharif, M.A. (2018). Copper (Cu) an Essential Redox-Active Transition Metal in Living System-A Review Article. American Journal of Analytical Chemistry, 9 (1): 15-26.

[63] Muyoma, P.W., Ramkat, R.C., Etela, I. \& Ododkuma, L. (2019). Assessment of Soil Metals Status in parts of Rivers State, Nigeria. Journal of Applied Sciences and Environmental Management, 23(3):545-550.

[64] Nachtigall, G.R., Nogueirol, R.C., L., Alleoni, R.F. \& Cambri, M.A. (2007). Copper concentration of vineyard soils as a function of $\mathrm{pH}$ variation and addition of poultry litter," Brazilian Archives of Biology and Technology, 50, (6): 941-948.

[65] Ndiokwere, C.L. (1984). A study of heavy metal pollution from motor vehicle emissions and its effect on roadside soil, vegetation and crops in Nigeria. Environ. Pollut. Ser. B: Chem. Phys., 7: 35-42.

[66] Nwankwoala, H.O. \& T Warmate, T. (2014). Subsurface Soil Characterization of a Site for Infrastructural Development Purposes in D/Line, Port Harcourt, Nigeria. American International Journal of Contemporary Research, 4 (6):139-148.

[67] Ogedengbe, K. \& C.O. Akinbile, C.O. (2004). Impact of Industrial Pollutants on Quality of Ground and Surface waters at Oluyole Industrial Estate, Ibadan, Nigeria, Nigerian. Journal of Technological Development, 4(2):139-144.

[68] Okunola, O.J., Uzairu, A., Ndukwe, G.I \& Adewusi, S.G. (2008). Assessment of Cd and Zn in Roadside Surface Soils and Vegetations along Some Roads of Kaduna Metropolis, Nigeria. Research Journal of Environmental Sciences, 2: 266-274.

[69] Pierzynski, G.M., Sims, J.T. \& Vance, G.F. (2000). Soils and Environmental Quality (2 ${ }^{\text {nd }}$ edition) CRC Press, London, UK.

[70] Qin, F., Ji, H., Li, Q., Guo, X., Tang, L., \& Feng, J. (2014). Evaluation of trace elements and identification of pollution sources in particle size fractions of soil from iron ore areas along the Chao River. Journal of Geochemical Exploration, 138, 33-49.

[71] Ramos, M.C. \& López-Acevedo, M. (2004). Zinc levels in vineyard soils from the Alt Penedès-Anoia region (NE Spain) after compost application. Advances in Environmental Research, 8, (3-4), 687-696.

[72] Rascio, N. \& Izzo, F.N. (2011). Heavy metal hyperaccumulating plants: How and why do they do it? And what makes them so interesting? Plant Science, 180, 169-181.

[73] Raskin, P. B., Kumar A. N., Dushenkov, S. \& Salt, D. E. (1994). "Bioconcentration of heavy metals by plants". Current Opinion in Biotechnology, 5 (3), 285-290.

[74] Ravenscroft, P., Brammer, H. \& Richards, K. (2009). Arsenic Pollution: A Global Synthesis. IWileyBlackwell.

[75] Rosas, I., Belmomt, R., Baez, A. \& Villalobos-Pietrini, R. (1989). Some aspects of the environmental exposure to chromium residues in Mexico. Water, Air, and Soil Pollution, 48 (3-4):463-475.

[76] Sahu, M. \& Kacholi, D.S. (2016). "Heavy metal levels in Amaranthus species from Chang'ombe-Mchicha area in Temeke District, Dar es Salaam, Tanzania," Asian Journal of Chemistry, 28 (5): 1123-1126. 
[77] Sharma, R.K., Agrawal, M. \& Marshall, F. (2008). Atmospheric deposition of heavy metals (Cu, Zn, Cd and $\mathrm{Pb}$ ) in Varanasi City, India," Environmental Modeling \& Assessment, 142 (1-3), 269-278.

[78] Sharma B., Singh S., Siddiqi N. J. (2014). Biomedical implications of heavy metals induced imbalances in redox systems. Biomed. Res. Int., 2014:640754. 10.1155/2014/640754

[79] Singh, A., Sharma, R.K., Agrawal, M. \& Marshall, F.M. (2010). "Risk assessment of heavy metal toxicity through contaminated vegetables from waste water irrigated area of Varanasi, India". Tropical Ecology, 51 (2), 375-387.

[80] Singh, J. \& Kalamdhad, A.S. (2011). Effects of Heavy Metals on Soil, Plants, Human Health and Aquatic Life. International Journal of Research in Chemistry and Environment, 1(2): 15-21.

[81] Tasrina, R.C. A. Rowshon, A., Mustafizur, A.M.R. Rafiqul, I \& Ali, M.P. (2015). Heavy metals contamination in vegetables and its growing soil," Journal of Environmental Analytical Chemistry, 2, (3): article 142.

[82] Tchounwou, P. B., Yedjou, C. G., Patlolla, A. K., \& Sutton, D. J. (2012). Heavy metal toxicity and the environment. In Luch, A. (Eds.), Molecular, clinical and environmental toxicology,101:133-164.

[83] Tinker, P.B. (1981). Levels, distribution and chemical forms of trace elements in food plants." Philosophical Transactions of the Royal Society B: Biological Sciences, 294 (1071): 41-55.

[84] Tsuwang, K.D., Ajigo, I.O. \& Lar, U.A. (2014). Assessment of Lead, Mercury and Arsenic in Soils of Anka Area, Northwestern Nigeria. International Journal of Science, $\quad$ Environment and Technology, 3 (1): 187197.

[85] Tsydenova, O., \& Bengtsson, M. (2011). Chemical hazards associated with treatment of waste electrical and electronic equipment. Waste Management, 31(1), 45-58.

[86] Turer, D. \& Maynard, J.B. (2003). Heavy metal contamination in highway soils. Comparison of corpus christi, TX and Cincinnati, OH shows organic matter is key to mobility. Clean Technol. Environ. Policy, 4: 235-245.

[87] Ukpadhi, F. \& Wokoma, O.A.F. (2019). Heavy metal concentrations in Dumpsite soil and its associated environment, Port Harcourt, Rivers State, Nigeria.

[88] Voutsa, D., Grimanis, A. \& Samara, C. (1996). Trace elements in vegetables grown in an industrial area in relation to soil and air particulate matter. Environmental Pollution, 94 (3), 325-335.

[89] Wagner, T. P. (2009). Shared responsibility for managing electronic waste: A case study of Maine, USA. Waste Management, 29(12), 3014-3021.

[90] Welch, A.H., Lico, M.S. \& Hughes, J.L. (1988). Arsenic in groundwater of the western United States. Ground Water, 26(3): 333-347.

[91] Welz, B. \& Sperling, M. (1999). Atomic Absorption Spectrometry (3 ${ }^{\text {rd }}$ edition) Wiley-VCH, VerlagGmbH, Weinheim, Germany.

[92] WHO (1971). The work of WHO, 1971: annual report of the Director-General to the World HealthAssembly and to the United Nations

[93] WHO/FAO (1996). "Codex general standard for contaminants and toxins in foods," Joint FAO/WHO joint food standards programme, Codex Alimentarious commission, Rome, Italy.

[94] WHO/UNEP. (1997). World Health Organization/ United Nations Environmental Programme. Water Pollution Control -A guide to the use of Water Quality Management Principles, case study of Nigeria, 14pp.

[95] WHO/FAO. (2001). Codex alimentarius commission. Food additives and contaminants. Joint FAO/WHO Food Standards Programme, ALINORM 10/12A.

[96] WHO/FAO. (2007). Joint FAO/WHO Food Standard Programme Codex Alimentarius Commission 13th Session. Report of the Thirty-Eight Session of the Codex Committee on Food Hygiene. Houston, TX, ALINORM 07/30/13.

[97] Young, R.A. (2005). Toxicity Profiles: Toxicity Summary of Cadmium, Risk Assessment Information System, vol. 8, University of Tannessee.

Citation: Iyama, W. A., Edori, O. S, “Assessment of Levels and Safe Factor Index of Heavy Metals in Soils Around DIOBU, Port Harcourt, Nigeria”, International Journal of Advanced Research in Chemical Science, 7(8), pp. 1-15. DOI: https:// doi.org/10.20431/2349-0403.0708001

Copyright: () 2020 Authors, this is an open-access article distributed under the terms of the Creative Commons Attribution License, which permits unrestricted use, distribution, and reproduction in any medium, provided the original author and source are credited. 